\title{
IMPACT OF NITROGEN AND POTASSIUM NUTRITION ON PAPAYA (PAWPAW) FRUIT QUALITY
}

\author{
IMPACTO DA NUTRIÇÃO NITROGENADA E POTÁSSICA NA QUALIDADE DE \\ FRUTOS DE MAMOEIRO FORMOSA
}

\author{
Eduardo Monteiro SANTOS ${ }^{1}$; Ítalo Herbert Lucena CAVALCANTE ${ }^{2}$; \\ Gabriel Barbosa da SILVA JÚNIOR ${ }^{3}$; Francisca Gislene ALBANO ${ }^{3}$ \\ 1. M.Sc. student in Soil Science and Plant Nutrition, Federal University of Piauí, Bom Jesus, PB, Brazil. \\ eduardomonteirosant@yahoo.com.br; 2. Department of Agronomy Engineering, Federal University of São Francisco Valley, Petrolina, \\ PE, Brazil. CNPq research fellow; 3. M.Sc. student in Plant Production, Federal University of Piauí, Bom Jesus, PB, Brazil.
}

\begin{abstract}
Pawpaw (Carica papaya L.), also known papaya, is a fruit species with economic and social importance for Brazil, the second main world producer. Although this characteristic the relationship between $\mathrm{N}$ and $\mathrm{K}$ nutrition and papaya fruit quality has been poorly studied. Thus, an objective with this study was to evaluate the effect of nitrogen and potassium for papaya (pawpaw) fruit quality produced in North eastern Brazil. The experimental design consisted of randomised blocks, with treatments distributed in a factorial arrangement (4 x 4), using four nitrogen doses $\left(320,400,480\right.$ and $560 \mathrm{~g}$ of N plant $\left.^{-1}\right)$ and four potassium doses $\left(380,475,570\right.$ e $665 \mathrm{~g} \mathrm{of} \mathrm{K}_{2} \mathrm{O}$ plant $\left.{ }^{-1}\right)$, containing with four replications of three plants each. The fruit characteristics, such as fruit mass, titratable acidity, soluble solids, pulp pH and fruit length and width, were recorded. The fruit qualityof pawpaw depend on nitrogen and potassium leaf concentration. The higher fruit quality parameters regarding to soluble solids, $\mathrm{pH}$, fruit length and fruit mass are associated to $45.30 \mathrm{~g} \mathrm{~kg}^{-1}$ leaf $\mathrm{N}$ concentration and 37.55 leaf $\mathrm{K}$ concentration.
\end{abstract}

KEYWORDS: Carica papaya L., Plant nutrition. Post harvest.

\section{INTRODUCTION}

Pawpaw (Carica papaya L.), also known papaya, is native to Central America but is now distributed throughout the tropical areas of the world (HUI, 2006), including Brazil, where this fruit species present economic and social importance, since it is the second main world producer (FAOSTAT, 2014).

Papaya is a fast and continuously growing plant, which provides fruits all the year round, thus an abundant supply of nutrients at regular intervals is needed to sustain good growth and production (FONTES et al., 2010; SANTOS et al., 2014). In a general form, an adequate supply of nitrogen and phosphorus should be provided during the early stages to ensure optimum foliage, trunk and root development, although, at the fruiting stage, potassium demand should be raised (PAULL; DUARTE, 2011).

Specifically for papaya Hui (2006) observed that fruit quality and yield of papaya fruits are greatly influenced by NK fertilizer application, and nitrogen presents especial hole because almost $23 \%$ of all nitrogen absorbed by papaya roots is exported to flowers and fruits (LYRA et al., 2010), thus nitrogen fertilizing with high amounts usually is associated to higher papaya yields and better fruit quality (MARINHO et al., 2008). Regarding to potassium, Römheld and Kirby (2010) argue that this nutrient is recognized as a quality element which improves major quality parameters of papaya fruits such as pulp thickness, i.e. edible part size of papaya fruits increase; it increases total soluble solids content and it decreases fruit titratable acidity. Additionally, Saure (2005) concluded that $\mathrm{N}$ and $\mathrm{K}^{+}$ are the elements most closely related to papaya fruit quality.

Despite nitrogen is the nutrient more directly correlated to higher increases of papaya yield, its effect on papaya fruit quality has been poorly quantified and, in most studies it is not favourable. Adversely, despite the economic importance of papaya for Brazil, an adequate fertilizing management for nitrogen and potassium has not being defined and accepted by researchers as a standard for high fruit quality and yields.

Hence, the present study aimed to evaluate the effect of nitrogen and potassium for papaya (pawpaw) fruit quality produced in North eastern Brazil.

\section{MATERIAL AND METHODS}

\section{Plant Material and Growth Conditions}

Papaya (Carica papaya L. pawpaw) plants cv. Caliman 01 propagated by seeds were used in this study. The study was conducted from November 2011 to December 2012 at "Campus 
Prof $^{\text {a }}$. Cinobelina Elvas", Federal University of Piaui, Piaui State, Brazil (North eastern Brazil).

The physical and chemical characteristics of the soil developed for the experiment are shown in Table 1. The climatic data regarding air temperature and air humidity (thermo-hygrometer Instrutemp ${ }^{\circledR}$, Brazil) and precipitation collected during the experiment are shown in Figure 1.

Table 1. Chemical and physical characteristics of the soil $(0-20 \mathrm{~cm}$ and $20-40$ soil depth) where the experiment was carried out.

\begin{tabular}{|c|c|c|c|}
\hline Soil characteristics & \multicolumn{3}{|c|}{ Value } \\
\hline & $0-20 \mathrm{~cm}$ & & $20-40 \mathrm{~cm}$ \\
\hline $\mathrm{pH}$ (in water) & $\overline{5.0}$ & & 4.8 \\
\hline $\mathrm{Ca}^{2+}$ & 1.6 & & 0.9 \\
\hline $\mathrm{Mg}^{2+}$ & 0.4 & & 0.2 \\
\hline $\mathrm{Ca}^{2+}+\mathrm{Mg}^{2+}$ & 2.0 & & 1.1 \\
\hline $\mathrm{Al}^{3+}$ & 0.0 & & 0.0 \\
\hline $\mathrm{H}^{+}+\mathrm{Al}^{3+}$ & 1.7 & & 1.3 \\
\hline $\mathrm{K}^{+}$ & 0.23 & & 0.11 \\
\hline CEC & 3.9 & & 2.5 \\
\hline $\mathrm{P}$ & 18.0 & & 14.0 \\
\hline Organic Matter & 1.0 & & 0.4 \\
\hline $\mathrm{Al}^{3+}$ saturation & 0.0 & & 0.0 \\
\hline Basis saturation & 57.0 & & 48.0 \\
\hline Clay & 60 & & 60 \\
\hline Silt & 20 & & 20 \\
\hline Sand & 920 & & 920 \\
\hline
\end{tabular}
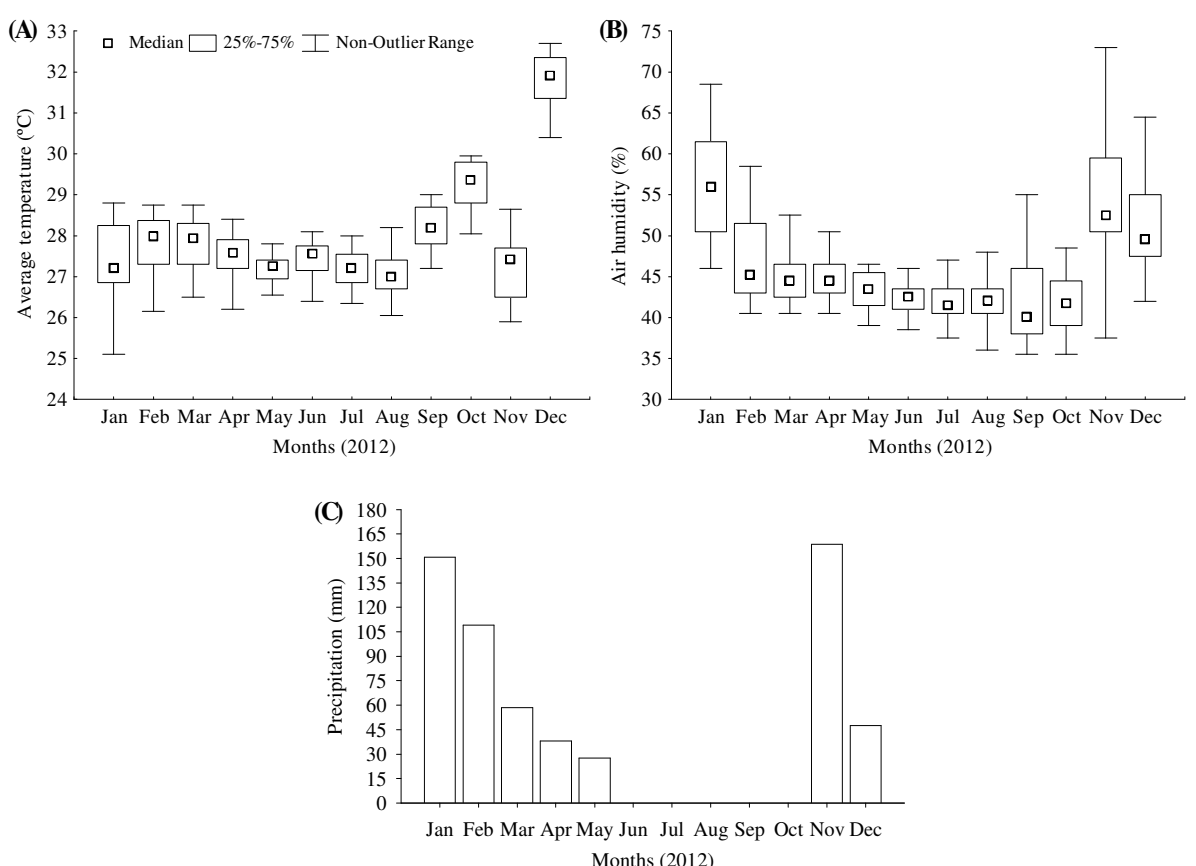

Figure 1. Average temperature, air humidity and precipitation during the execution of the experiment. 
The plants, spaced with $3.8 \mathrm{~m}$ between main rows, $2.0 \mathrm{~m}$ between secondary rows and $1.8 \mathrm{~m}$ between plants, were daily drip-irrigated with one self-regulating emitter per plant, for a flow of $2.8 \mathrm{~L}$ $\mathrm{h}^{-1}$, following the Kc defined by Coelho Filho et al. (2006) for papaya. Each hole $(40 \times 40 \times 40 \mathrm{~cm})$ at 60 days before planting received $15 \mathrm{~L}$ of goat manure (C:N, 17:1) and $169 \mathrm{~g}$ of simple superphosphate $\left(\begin{array}{lll}18 \% & \mathrm{P}_{2} \mathrm{O}_{5}\end{array}\right)$. All experiment area was limed with $1.22 \mathrm{t} \mathrm{ha}^{-1}$ at 60 days before the beginning of the experiment following soil analysis contained in Table 1.

During the execution of the experiment, all pants were fertilized with $167 \mathrm{~g}$ of simple superphosphate $\left(18 \% \mathrm{P}_{2} \mathrm{O}_{5}\right)$ at each 90 days. $\mathrm{N}$ and $\mathrm{K}$ fertilizing, following the treatments, were performed monthly following recommendations of Costa and Costa (2003) using urea (45\% of N) and potassium chloride $\left(60 \%\right.$ of $\left.\mathrm{K}_{2} \mathrm{O}\right)$ as $\mathrm{N}$ and $\mathrm{K}$ sources, respectively.

The cultural practices performed in the experiment followed the instructions of Paull and Duarte (2011).

\section{Treatments and Experimental Design}

The experimental design consisted of randomised blocks with treatments distributed in a factorial arrangement ( $4 \times 4$ ) of four nitrogen doses (320, 400, 480 and $560 \mathrm{~g}$ of $\mathrm{N}_{\text {plant }}{ }^{-1}$ ) and four potassium doses $\left(380,475,570\right.$ e $665 \mathrm{~g}$ of $\mathrm{K}_{2} \mathrm{O}$ plant $^{-1}$ ) with four replications of three plants each.

\section{Data Gathered and Statistical Analysis}

For $\mathrm{N}$ and $\mathrm{K}$ leaf content analysis, leaf samples were taken from normal shoots, at the beginning of each blooming, i.e. at 120 days after planting. According to recommendations of Malavolta et al. (1997), the "F" leaves following papaya plant taxonomy, were collected to perform the nutritional analysis. Leaves were chemically analysed after washing and rinsing with distilled water and drying at $70^{\circ} \mathrm{C}$ for $48 \mathrm{~h}$. The $\mathrm{N}$ contents were determined by the Kjeldahl method (BREMMER, 1965) and $\mathrm{K}$ contents were determined by atomic-absorption spectrophotometry (CHAPMAN; PRATT, 1961).

During the fruit harvest time, ten fruits per parcel were manually harvested when they were one-quarter to one-half ripe. The fruits were placed in paper bags and taken to the Food Laboratory at the Federal University of Piaui, Bom Jesus, Brazil. This parameter for fruit selection was recommended by Paull and Duarte (2011) for commercial farms.

The fruit analyses of the papaya (pawpaw) fruits included the usual parameters: i) the fruit mass was measured using a Sartorious ${ }^{\circledR}$ (Göttingen, Germany) brand precision balance $(0.01 \mathrm{~g}$ precision) and expressed in $\mathrm{g}$; ii) for the titratable acidity (TA), $20 \mathrm{~g}$ of macerated fruit pulp was taken from yellow passion fruits and brought to a final volume of $100 \mathrm{~mL}$ by adding distilled water. A 20$\mathrm{mL}$ sample was taken from the mixture, and three to four drops of phthalein were used as an indicator. This suspension was titrated with $0.1 \mathrm{~N}$ sodium hydroxide $(\mathrm{NaOH})$. The results were expressed as a percentage of citric acid; iii) the soluble solids (SS), expressed as ${ }^{\circ}$ Brix, were measured using an $\mathrm{Abbe}^{\circledR}$ refractometer (Bausch and Lomb, Rochester, NY, USA); iv) the pulp $\mathrm{pH}$ was measured using a Marconi ${ }^{\circledR} \mathrm{pH}$ meter; $\mathrm{v}$ ) fruit width and length $(\mathrm{cm})$; and vi) pulp percentage, obtained through a direct relation of pulp mass with fruit mass. The chemical analyses of fruits followed the methodology described by Instituto Adolfo Lutz (IAL, 2008).

Statistical analyses included analysis of variance (ANOVA) ) using combined data of two consecutive harvests, regression analysis and correlation analysis between leaf nitrogen concentration, leaf potassium concentration and fruit quality variables. All calculations were performed using the Sigmaplot software (SPSS, version 10.0, Chicago), and the terms were considered significant at $p \leq 0.01$.

\section{RESULTS AND DISCUSSION}

\section{Nitrogen}

In the present study three correlation results were relevant for nitrogen leaf concentration and pawpaw fruit quality. Leaf $\mathrm{N}$ concentration was positively and significantly correlated with fruit length, i.e. leaves with higher $\mathrm{N}$ concentrations had also fruits with higher length, with a significant ( $p \leq$ $0.01)$ correlation coefficient $(r)$ of 0.88 . This result could be explained by the effects of $\mathrm{N}$ on plants, since Pessarakli (2014) argue that nitrogen affects plant growth in two ways: by influencing leaf area; and by affecting the photosynthetic capacity of foliage. Thus, leaf nitrogen can be expected to affect photosynthesis rates and carbohydrate allocation, and consequently promote a higher fruit growth. Accordingly, the results are consistent with the findings Kirimi et al. (2011) who observed that higher leaf nitrogen improved fruit quality by prolonging shelf life, increasing fruit size, colour and taste. However, the degree of association depends on several factors, such as plant species and plant requirement for $\mathrm{N}$, showing that excessive $\mathrm{N}$ also could reduce fruit quality such as registered for Aslantas et al. (2007), who reported that nitrogen 
application increases growth and leaf nitrogen content, but its excess negatively affects fruit quality.

Fruit length presented a linear adjustment of the data with a minimum fit of 0.80 , with a peak at 45.29 Leaf $\mathrm{N}$ concentration (Figure 2A). Whether compared with the standardized foliar levels of nitrogen established by Malavolta et al. (1997), it's possible to infer that adequate $\mathrm{N}$ supplied plants

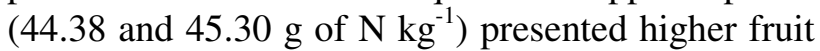
length, results that proves the importance of a balanced $\mathrm{N}$ nutritional status for fruit quality and, specifically for fruit length. Pawpaw fruits correlated with leaf $\mathrm{N}$ concentration (Figure 2A) presented length shorter than those reported by Souza et al. (2009) and Lima et al. (2009).
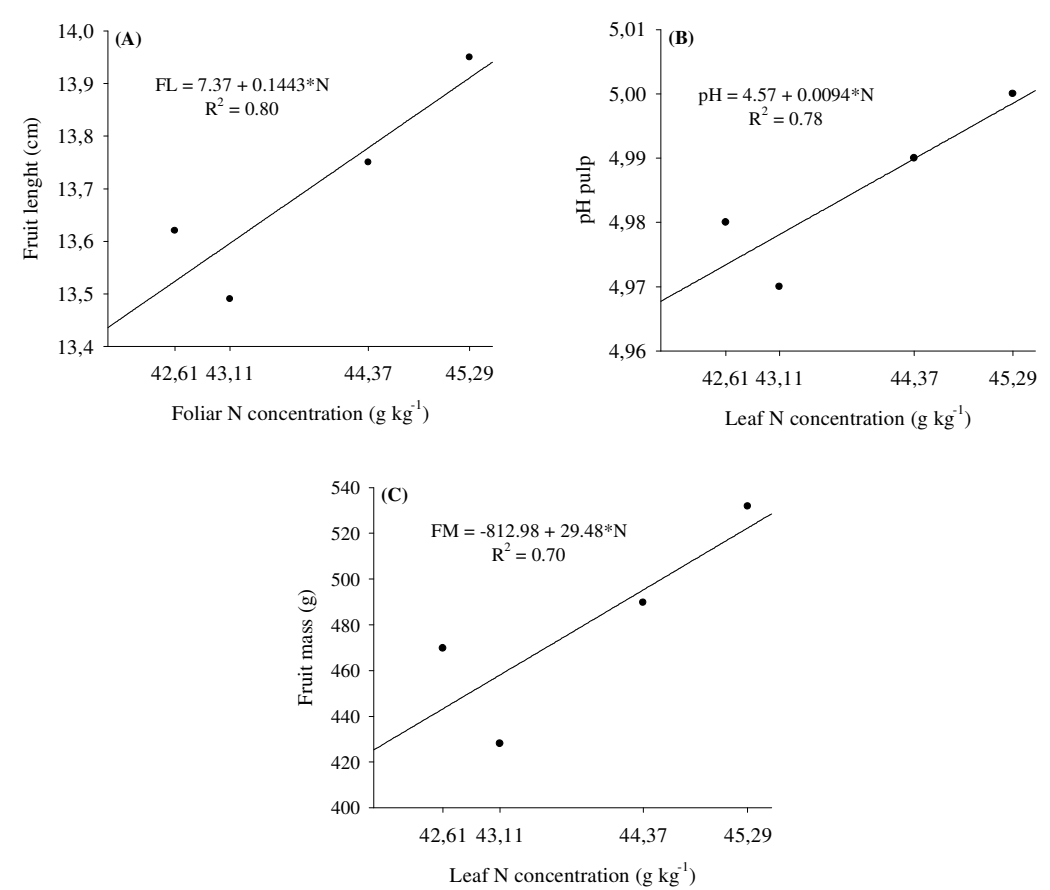

Figure 2A-B-C. Relationship between leaf N concentration and fruit length (A), pulp pH (B) and fruit mass (C) of pawpaw.

Pulp $\mathrm{pH}$ was positively correlated with leaf $\mathrm{N}$ concentration $(\mathrm{r}=0.93, p \leq 0.01)$, a correlation considered by Ferreira (2000) as 'high'. This way, Diehl et al. (2013) reported that some foods are required to be preserved based on their $\mathrm{pH}$ levels, e.g. fruits with a $\mathrm{pH}$ of 4.6 or less must be preserved because of their acidity. According to the same authors, pulp $\mathrm{pH}$ has especial importance for pulp and juice industries because more acid fruits (lower $\mathrm{pH})$ reduce the addition of artificial acid components, and, on the other hand, for consumption as fresh fruit less acid fruits (higher $\mathrm{pH})$ are required.

Fruit $\mathrm{pH}$ increased with leaf $\mathrm{N}$ concentration increase until $45.30 \mathrm{~g} \mathrm{~kg}^{-1}$ losing this tendency and decreasing until $42.61 \mathrm{~g} \mathrm{~kg}^{-1}$ (Figure 2B), but, independently, all treatments presented the minimum pulp $\mathrm{pH}$ required by food industry, which is 4.0 (Anonymous, 2000).

Although the physicochemical quality of papaya fruits (including $\mathrm{pH}$ ) is influenced by various agronomic practices, nitrogen fertilizing and planting time of the year are important parameters (HUI, 2006). However, Marinho et al. (2001) registered no effect of $\mathrm{N}$ of papaya fruit quality, result caused by the low nitrogen doses applied, according to author's discussion.

The $\mathrm{pH}$ values registered in the present study (Figure 2B) are compatible to those quoted in the scientific literature such as 5.12-5.19 (SOUZA et al., 2009) and 5.06-5.10 (LIMA et al. (2009). The relatively high $\mathrm{pH}$ of papaya fruits is caused by its very low titratable acidity (nearly $0.10 \%$ ).

Average fruit mass presented a linear adjustment of the data with a minimum fit of 0.70 , with a peak at 45.29 leaf $\mathrm{N}$ concentration (Figure 2C). This way, it is important to note that lower leaf $\mathrm{N}$ concentration promotes lower leaf $a$ and $b$ chlorophyll concentrations that contributes for decrease the photosynthetic hate and growth of papaya plants (CRUZ et al., 2007). These authors also concluded that leaf area and fruit development 
are also dependent of papaya $\mathrm{N}$ status, thus in agreement with the present study. In addition, the fruits produced in this study are lighter, on average, than those recorded by Migliaccio et al. (2010) and Lima et al. (2009), but compatible to average of Garcia et al. (2007), all researchers developed with papaya under field conditions.

\section{Potassium}

Correlation results between potassium leaf concentration and pawpaw fruit quality revealed that among all variables recorded, only pulp $\mathrm{pH}$ and soluble solids were significant.

Soluble solids presented a linear adjustment of the data with a minimum fit of 0.96, with a peak at 37.55 leaf $\mathrm{K}$ concentration (Figure 3). This present finding was also reported by Kumar et al.
(2006) who claimed that potash fertilizer use improved major quality parameters of papaya fruits such as the sweetness of papaya (SS), latex yield and its quality; and Campos et al. (2007) registered weightier and sweeter fruits in plants submitted to larger amounts of potassium, agreeing with Marschner (2012), who argue that potassium is known to promote sugar translocation in plants, thus it increases the sugar content as well as soluble solids in fruits, including papaya, as confirmed by Souza et al. (2009) and Kumar et al. (2010).

Indeed, Pessarakli (2014) explains that potassium is recognized as a quality element which improves major quality parameters of papaya fruits such as pulp thickness, i.e. edible part size of papaya fruits increase; it increases total soluble solids content and it decreases fruit titratable acidity.
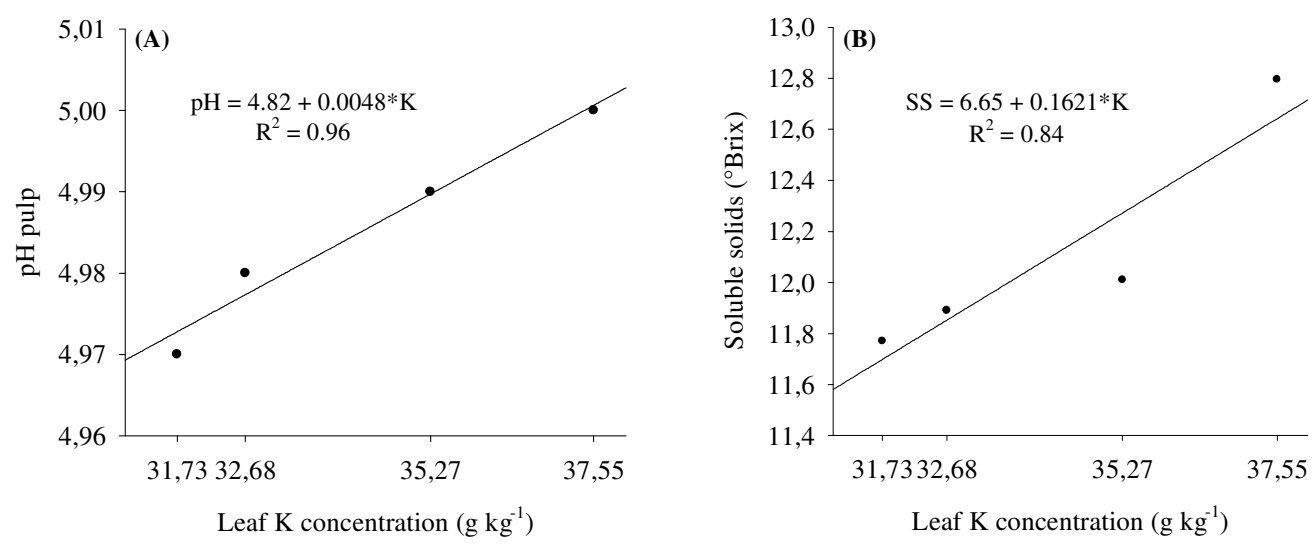

Figure 3A-B. Relationship between leaf $\mathrm{K}$ concentration and pulp $\mathrm{pH}$ (A) and fruit soluble solids (B) of pawpaw.

Whether compared soluble solids results of the present study with those registered in the scientific literature, it is possible to infer that soluble solids from plants which presented from 37.28 to 37.55 are close to the results reported by Argañosa et al. (2008) and Souza et al. (2009), and higher than average values obtained by Fontes et al. (2012), all of them in studies about papaw. In addition, it is important to note that, independently of the higher soluble solids average of the highest $\mathrm{K}$ leaf concentration, all plants presented soluble solids values above the limit of $11^{\circ}$ brix required by the industry (ANONYMOUS, 2000) and $11.5^{\circ}$ brix required by international market (ALVES et al., 2003).

Fruit $\mathrm{pH}$ increased with leaf $\mathrm{K}$ concentration increase until $37.55 \mathrm{~g} \mathrm{~kg}^{-1}$ losing this tendency and decreasing until $32.59 \mathrm{~g} \mathrm{~kg}^{-1}$ (Figure 3). Pulp pH recorded are compatible to those (5.96-5.98) informed by Fontes et al. (2010) and (5.44-5.61) registered by Argañosa et al. (2008). Plants from all treatments produced fruits with $\mathrm{pH}$ average values above the minimum limit of 4.0 required by the industry specifically for papaya (ANONYMOUS, 2000).

Whether compared with the standardized foliar levels of potassium established by Malavolta et al. (1997), it is possible to infer that all treatments promoted leaf $\mathrm{K}$ averages above the adequate range, although no visual toxicity symptoms have been registered. This result explains why all treatments reached the minimum average values required by papaya industry for processed fruits, since according to Römheld and Kirby (2010) the physiological basis for the need of adequate $\mathrm{K}$ status of plants in quality development of crops is well recognized, i.e. potassium acts in plants increasing photosynthesis as consequence of a more efficient photosynthetic activity, increasing leaf size and number and more effective translocation of photoassimilates and 
amino $\mathrm{N}$ compounds into reproductive organs via the phloem.

\section{CONCLUSIONS}

The fruit quality of pawpaw depend on nitrogen and potassium leaf concentration;
The higher fruit quality parameters regarding to soluble solids, $\mathrm{pH}$, fruit length an fruit mass are associated to $45.29 \mathrm{~g} \mathrm{~kg}^{-1}$ leaf $\mathrm{N}$ concentration and 37.55 leaf $\mathrm{K}$ concentration

RESUMO: O mamoeiro Formosa (Carica papaya L.) é uma espécie frutífera de importância social e econômica para o Brasil, o segundo maior produtor mundial. Apesar dessa característica, a relação entre a nutrição com $\mathrm{N}$ e $\mathrm{K}$ e a qualidade de frutos têm sido pouco estudada. Assim, objetivou-se com o presente trabalho avaliar o efeito da nutrição nitrogenada e potássica na qualidade de frutos do mamoeiro Formosa no Nordeste brasileiro. Adotou-se o delineamento em blocos casualizados, em esquema fatorial 4 x 4, correspondentes a doses de nitrogênio em cobertura (320, 400 , 480 e $\left.560 \mathrm{~g} \mathrm{planta}^{-1}\right)$ e doses de potássio em cobertura $\left(380,475,570\right.$ e $\left.665 \mathrm{~g}_{\text {planta }}{ }^{-1}\right)$, contendo quatro repetições de três plantas por parcela cada. A qualidade dos frutos foi determinada, avaliando-se a massa de fruto, acidez titulável, sólidos solúveis, pH da polpa, diâmetro longitudinal e transversal dos frutos. A qualidade de frutos de mamão formosa depende da concentração foliar de nitrogênio e potássio. Os melhores resultados de sólidos solúveis, pH de polpa, diâmetro longitudinal de frutos estão associados às concentrações foliares de $45,30 \mathrm{~g} \mathrm{~kg}^{-1}$ de $\mathrm{N}$ e $37,55 \mathrm{~g} \mathrm{~kg}^{-1} \mathrm{de} \mathrm{K}$.

PALAVRAS-CHAVE: Carica papaya L. Nutrição de plantas. Pós-colheita.

\section{REFERENCES}

ALVES, F. L. A cultura do mamão Carica papaya L. no mundo. In: MARTINS, D. S.; COSTA, A. F. S. (eds.). A cultura do mamoeiro: tecnologias de produção. Vitória: Incaper, 2003. p. 13-34.

ANONYMOUS. 2000. Instrução normativa nº 01, de 07 de Janeiro de 2000, Seção I. Brasília, Brazil, Ministério da Agricultura e do Abastecimento.

ARGAÑOSA, A. C. S. J.; RAPOSO, M. F. J.; TEIXEIRA, P. C. M.; MORAIS, A. M. M. B. Effect of cut-type on quality of minimally processed papaya. Journal of the Science of Food and Agriculture, Malden, v. 88, n. 12, p. 2050-2060, 2008.

ASLANTAS, R.; ÇAKMAKÇI, R.; SAHIN, F. Effect of plant growth promoting rhizobacteria on young apples trees growth and fruit yield under orchard conditions. Scientia Horticulturae, Amsterdan, v. 111, n. 4, p. 371377, 2007.

BREMMER, J. M. Total nitrogen. In: BREMMER, J. M. Methods of analysis. New York: Academic Press, 1965. p. 1149-1178.

CAMPOS, V. B.; CAVALCANTE, L. F.; DANTAS, T. A. G.; MOTA, J. K. M.; RODRIGUES, A. C.; DINIZ, A. A. Caracterização Física e Química de Frutos de Maracujazeiro Amarelo sob Adubação Potássica,

Biofertilizante e Cobertura Morta. Revista Brasileira de Produtos Agroindustriais, Campina Grande, v. 9, n. 1, p. 59-7, 2007.

CHAPMAN, H. D.; PRATT, P. F. Method of analysis for soils, plants and waters. Berkeley: Agriculture Publishing Office, 1961. 309 p.

COELHO FILHO, M. A.; COELHO, E. F.; CRUZ, J. L. Uso da transpiração máxima de mamoeiro para o manejo de irrigação por gotejamento em regiões úmidas e sub-úmidas. Cruz das Almas: Embrapa Mandioca e Fruticultura Tropical, 2006. 30p. 
COSTA, A. N.; COSTA, A. F. S. Nutrição e adubação. In: MARTINS, D. S.; A. F. S., COSTA (eds.). A cultura do mamoeiro: tecnologias de produção. Vitória: Incaper, 2003. p. 201-227.

CRUZ, J. L.; PELACANI, C. R.; CARVALHO, J. E. B.; SOUZA FILHO, L. F.; QUEIROZ, D. C. Níveis de nitrogênio e a taxa fotossintética do mamoeiro "golden". Ciência Rural, Santa Maria, v. 37, n. 1., p. 64-71. 2007. http://dx.doi.org/10.1590/S0103-84782007000100011

DIEHL, D. C.; SLOAN, N. L.; BRUHN, C.M.; SIMONNE, A. H.; BRECHT, J. K.; MITCHAM, E. J. Exploring produce industry attitudes: relationships between postharvest handling, fruit flavor, and consumer purchasing. HortTechnology, Alexandria, v. 23, n. 5, p. 642-650, 2013.

FAO. Production-crops. Available in: <http://faostat.fao.org/site/339/default.aspx>. Access in: 12 Jan. 2014.

FERREIRA, P. V. F. Estatística experimental aplicada à agronomia. Maceió: Edufal, 2000. 350p.

FONTES, R. V.; VIANA, A.; PEREIRA, M. G.; OLIVEIRA, J. G.; SILVA, D. M.; BROETTO, S. G.; SILVA, M. M. Diferentes espaçamentos de plantio e níveis de adubação sobre a atividade de redutase do nitrato em folhas do híbrido de mamoeiro UENF/CALIMAN-01. Revista Brasileira de Fruticultura, Jaboticabal, v. 32, n. 4, p. 1138-1145, 2010.

FONTES, R. V.; VIANA, A. P.; PEREIRA, M. G.; OLIVEIRA, J. G.; VIEIRA, H. D. Manejo da cultura do híbrido de mamoeiro (Carica papaya L.) do grupo 'Formosa' Uenf/Caliman - 01 para melhoria na qualidade do fruto com menor aplicação de adubação NPK. Revista Brasileira de Fruticultura, Jaboticabal, v. 34, n. 1, p. 43-151, 2012.

GARCIA, F. C. H.; BEZERRA, F. M. L.; FREITAS, C. A. S. Níveis de irrigação no comportamento produtivo do mamoeiro Formosa na Chapada do Apodi, CE. Revista Ciência Agronômica, Fortaleza, v. 38, n. 2, p. 136$141,2007$.

HUI, Y. H. Handbook of fruits and fruit processing. 2nd ed. Iowa: Blackwell Publishing, 2006. 688p. http://dx.doi.org/10.1002/9780470277737

INSTITUTO ADOLFO LUTZ. Métodos físico-químicos para análise de alimentos. São Paulo: Instituto Adolfo Lutz, 2008. 1020 p.

KIRIMI, J. K.; ITULYA, F. M.; MWAJA, V. N. Effects of nitrogen and spacing on fruit yield of tomato. African Journal of Horticultural Science, Nairobi, v. 5, n. 1, p. 50-60, 2011.

KUMAR, N.; SOORIANATHASUNDARAM, K.; MEENAKSHI, N.; MANIVANNAN, M. I.; SURESH, J.; NOSOV, V. Balanced fertilization in papaya (Carica papaya L.) for higher yield and quality. Acta Horticulturae, Wageningen, n. 851, p. 357-362, 2010.

KUMAR, N.; MEENAKSHI, N.; SURESH, J.; NOSOV, V. Effect of potassium nutrition on growth, yield and quality of papaya (Carica papaya L.). Indian Journal of Fertilizers, New Delhi, v. 2, n. 4, p. 43-47, 2006.

LIMA, L. M.; MORAIS, P. L. D.; MEDEIROS, E. V.; MENDONÇA, V.; XAVIER, I. F.; LEITE, G. A. Qualidade pós-colheita do mamão Formosa 'Tainung 01' comercializado em diferentes estabelecimentos no município de Mossoró-RN. Revista Brasileira de Fruticultura, Jaboticabal, v. 31, n. 3, p.902-906, 2009.

LYRA, G. B.; PONCIANO, N. J.; SOUZA, P. M.; SOUSA, E. F.; LYRA, G. B. Viabilidade econômica e risco do cultivo de mamão em função da lâmina de irrigação e doses de sulfato de amônio. Acta

ScientiarumAgronomy, Maringá, v. 32, n. 3, p. 547-554, 2010.

http://dx.doi.org/10.4025/actasciagron.v32i3.2451 
MALAVOLTA, E.; VITTI, G. C.; OLIVEIRA, S. A. Avaliação do estado nutricional das plantas: princípios e aplicações. 2nd ed. Piracicaba: Associação Brasileira para Pesquisa da Potassa e do Fosfato. 1997. 281 p.

MARINHO, A. B.; BERNARDO, S.; SOUSA, E. F.; PEREIRA, M. G.; MONNERAT, P. H. Produtividade e qualidade de frutos de mamão cultivar 'golden' sob diferentes lâminas de irrigação e doses de potássio no norte de Espírito Santo. Engenharia Agrícola, Jaboticabal, v. 28, n. 3, p. 417-426, 2008.

MARINHO, C. S.; OLIVEIRA, M. A. B.; MONNERAT, P. H.; VIANNI, R.; MALDONADO, J. F. Fontes e doses de nitrogênio e a qualidade dos frutos do mamoeiro. Scientia Agricola, Piracicaba, v. 58, n. 2, p. 345348, 2001. http://dx.doi.org/10.1590/S0103-90162001000200018

MARSCHNER, H. Mineral nutrition of higher plants. 3rd ed. London: Academic Press, 2012. 645p.

MIGLIACCIO, K. W.; SCHAFFERA, B.; CRANEA, J. H.; DAVIES, F. S. Plant response to evapotranspiration and soil water sensor irrigation scheduling methods for papaya production in south Florida. Agricultural Water Management, Amsterdan, v. 97, n. 10, p. 1452-1460, 2010.

PAULL, R. E.; O. DUARTE. Tropical fruits. 2nd ed. London: CAB International, 2011. 400p.

PESSARAKLI, M. Handbook of plant and crop physiology. 3rd ed. New York: Marcel Dekker, 2014. $1031 \mathrm{p}$.

RÖMHELD, V.; KIRKBY, E.A. Research on potassium in agriculture: needs and prospects. Plant Soil, New York, v. 335, n. 2, p. 155-180, 2010. http://dx.doi.org/10.1007/s11104-010-0520-1

SANTOS, E. M., CAVALCANTE, Í. H. L., SILVA JÚNIOR, G. B., ALBANO, F. G., LIMA, F. N., SOUSA, A. M., CAVALCANTE, L. F. Estado nutricional do mamoeiro formosa (cv. Caliman 01) em função de adubação com NK e espaçamento de plantio. Comunicata Scientiae, Bom Jesus, v. 5, n. 3, p. 229-240, 2014.

SAURE, M. C. Calcium translocation to fleshy fruit: Its mechanism and endogenous control. Scientia Horticulturae, Amsterdan, v. 105, n. 1, p. 65-89, 2005.

SOUZA, T. V.; COELHO, E. F.; PAZ, V. P. S.; LEDO, C. A. S. Avaliação física e química de frutos de mamoeiro 'Tainung $n^{\circ} 1$ ', fertirrigado com diferentes combinações de fontes nitrogenadas. Revista Brasileira de Ciências Agrárias, Recife, v. 4, n. 2, p. 179-184, 2009. http://dx.doi.org/10.5039/agraria.v4i2a10 